\title{
Legal Corruption and Dissatisfaction with Democracy in the European Union
}

\section{Gustavo Gouvêa Maciel \& Luís de Sousa}

\section{Social Indicators Research}

An International and Interdisciplinary Journal for Quality-of-Life Measurement

ISSN 0303-8300

Volume 140

Number 2

Soc Indic Res (2018) 140:653-674

DOI 10.1007/s11205-017-1779-x

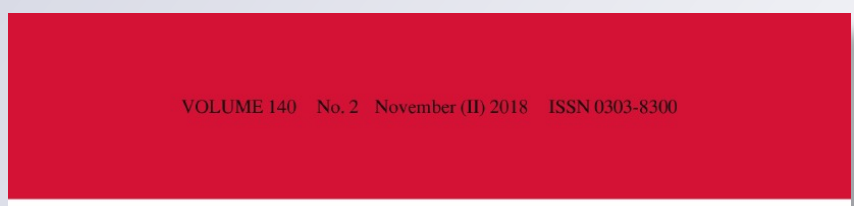

SOCIAL INDICA TORS

R ES E A R C H

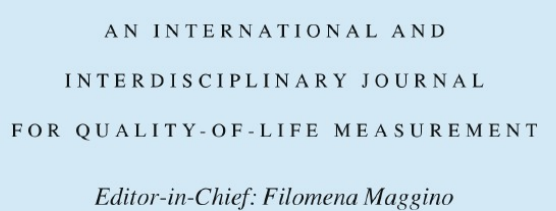

Editor-in-Chief: Filomena Maggino

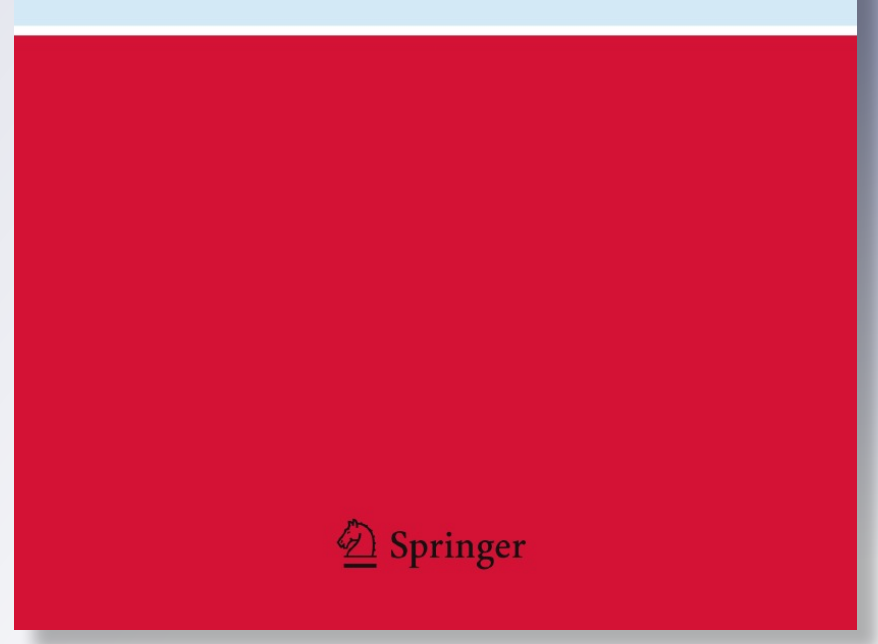


Your article is protected by copyright and all rights are held exclusively by Springer Science+Business Media B.V.. This e-offprint is for personal use only and shall not be selfarchived in electronic repositories. If you wish to self-archive your article, please use the accepted manuscript version for posting on your own website. You may further deposit the accepted manuscript version in any repository, provided it is only made publicly available 12 months after official publication or later and provided acknowledgement is given to the original source of publication and a link is inserted to the published article on Springer's website. The link must be accompanied by the following text: "The final publication is available at link.springer.com". 


\title{
Legal Corruption and Dissatisfaction with Democracy in the European Union
}

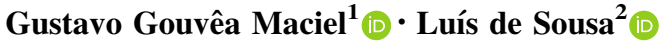

Accepted: 21 October 2017/Published online: 9 November 2017

(C) Springer Science+Business Media B.V. 2017

\begin{abstract}
Two developments have marked EU democracies, with different levels of incidence and intensity, during the past two decades: the decline in support for democracy and the spread of corruption. Most individual-level analyses have identified the incumbent's economic performance or government effectiveness as sufficient explanations of citizens' growing dissatisfaction with democracy; whilst corruption has been downplayed as an explanatory variable by these multifactor analyses. We contend that this has partly to do with conceptual and methodological failings in the way perceptions about the phenomenon are measured. Defining corruption as abuse of office is insufficient to understand how perceptions about the decline of ethical standards in public life can be relevant to shape specific support for democracy. In this article, we propose an alternative conceptualization that goes beyond what is proscribed in the penal codes and special criminal laws, which the literature has recently defined as legal/ institutional corruption, and demonstrate how it can offer an interesting explanation of citizens' perceptions of the way democracy works in a European context (EU-27 member states).
\end{abstract}

Keywords Legal corruption · Institutional corruption · Democracy · Dissatisfaction · European Union

The opinions expressed in this article are the Gustavo Gouvêa Maciel's own and do not reflect the official view of FUNAG.

Electronic supplementary material The online version of this article (https://doi.org/10.1007/s11205-0171779-x) contains supplementary material, which is available to authorized users.

Luís de Sousa

luis.sousa@ics.ulisboa.pt

Gustavo Gouvêa Maciel

gustavo.maciel@ua.pt

1 Fundação Alexandre de Gusmão (FUNAG), Esplanada dos Ministérios, Bloco H, Anexo II, Térreo, Zona Cívico-Administrativa, Brasília, DF CEP: 70170-900, Brazil

2 Institute of Social Sciences, University of Lisbon (ICS-UL), Av. Professor Aníbal de Bettencourt, 9, 1600-189 Lisbon, Portugal 


\section{Introduction}

Following the impact of the 2008/10 economic and financial crisis, levels of satisfaction with democracy declined to record figures (Curini et al. 2012; Leiter and Clark 2015; Polavieja 2013; Van Erkel and Van Der Meer 2016) in Europe, in particular in bailout countries (De Sousa et al. 2014; Memoli 2016; Sanches and Gorbunova 2016; Teixeira et al. 2014) and perceptions on the extension of corruption also deteriorated to worrisome levels (European Commission 2014). Two approaches have been used to try to understand the interplay of these cross-country tendencies: economic and institutional-oriented explanations.

Most individual-level analyses have identified the personal economic situation or perceptions on government effectiveness as sufficient to determine the growing dissatisfaction with democracy (Lewis-Beck 1988; Magalhães 2014, 2016; Newton 2006; Norpoth 1996; Polavieja 2013; Quaranta and Martini 2017; Teixeira et al. 2014; Waldron-Moore 1999). The incumbent's poor record in economic management or the lack of correspondence between people needs and expectations and policy outcomes are still the most widely accepted explanations for citizens' specific support. People feel dissatisfied with the way their democracy works because they do not see their problems solved and their quality of life improving. In other words, notwithstanding model specifications and data limitations, government effectiveness appears in most recent analyses as the strongest macro-level predictor of support for democracy (Magalhães 2014, p. 77).

Another set of explanations that have been gaining some recognition in recent years has to do with the quality of government performance-people feel dissatisfied because institutions are not performing according to universalistic ethical standards and safeguarding and promoting the public good. Instead they are perceived as being (ab)used for the benefit of a few (Aarts and Thomassen 2008; Holmberg and Rothstein 2012; Linde 2012; Philp 2001; Rothstein 2009, 2011; Rothstein and Teorell 2008; Wagner et al. 2009). According to this perspective, political corruption produces effects on the levels of (dis)satisfaction with the democratic functioning because it represents not only the commitment (or at least the perception of the commitment) of illicit acts, but also a complex set of behaviours that influences on policy-making efficiency (Dahlberg et al. 2015, p. 22).

Although there is a general intuition that the increased public awareness and condemnation of corruption can have a negative impact on levels of regime satisfaction in advanced democracies (De Sousa 2002, 2005; Della Porta and Mény 1997; Lambsdorff 2006; Rock 2009; Treisman 2000; Warren 2004), so far, the interplay between these two dynamics is still under-examined. This being said, recent empirical studies suggest that corruption can be highly corrosive to public support for democracy (Anderson and Tverdova 2003; Bailey and Paras 2006; Canache and Allison 2005; Fackler and Lin 1995; Morris and Klesner 2010; Seligson 2002). However, the tendency to exclude corruption as predictor of public support for democracy, given the dynamic complexity of the parameters that delimit its conceptual applicability, persists. Most multilevel analyses so far have dismissed corruption as an explanatory factor or at best cannot see a consistent pattern across the cases (Magalhães 2014, p. 77), because they have insisted in using a strict conceptualization of corruption as an illicit conduct mainly focused on personal experience (victimisation). ${ }^{1}$

\footnotetext{
${ }^{1}$ Mainstream conceptualisations of corruption tend to focus on bribery and relate to what is known as pocketbook evaluations, i.e. judgements driven by personal experience (see Klašnja et al. 2014, p. 70;
} 
The major contributions of this article are (1) to overcome these conceptual and methodological failings by adopting an alternative conceptualization of corruption that goes beyond what is proscribed in the penal codes and special criminal laws-which the literature has recently defined as institutional (Lessig 2013; Light 2013; Newhouse 2014; Thompson 2013) or legal (Kaufmann and Vicente 2011) corruption-and (2) to demonstrate that perceptions about legal/institutional corruption can offer an interesting explanation of public support for democracy in the European Union (EU). ${ }^{2}$

The article is organized in four parts. First, we explore theoretically the relationship between legal corruption and dissatisfaction with democracy $(D w D) .{ }^{3}$ Then, we present the methodology applied to understand the dynamics of such relationship. At this point, we operationalize the variables, create an index to assess legal/institutional corruption, ${ }^{4}$ and detail the econometric technique used. Next, we show how Europe scores in terms of corruption and $D w D$ and run logistic multilevel regressions to find that legal/institutional corruption (in contrast with corruption as a criminal offence) represents a solid explanatory factor for the evidenced declining levels of democratic performance in the European context. Finally, we argue that focusing primarily on individual sociographic characteristics and/or on macroeconomic factors is a way to overshadow important political determinants of dissatisfaction, in which legal corruption plays an important role. Anti-corruption strategies should then give emphasis to a more nebulous, pervasive, and resilient kind of corruption to conquer back the hearts and minds of dissatisfied democrats.

\section{A Sociotropic Linkage Between Legal Corruption and Dissatisfaction with Democracy}

Corruption is often avoided or dismissed as a predictor of public support for democracy, given the dynamic complexity of the parameters that delimit its conceptual applicability. Indeed, social judgments regarding corruption are based on two sets of standards:(1) legal

Footnote 1 continued

Klašnja and Tucker 2013, p. 537), in contrast to a conceptualization of corruption linked to a broader moral (and also political) decay of the quality of government performance, the so-called sociotropic evaluations, i.e. judgements which take into account the notion of collective interest (Meehl 1977, p. 14).

227 member states of the EU were evaluated here: Austria (AT), Belgium (BE), Bulgaria (BG), Cyprus (CY), Czech Republic (CZ), Denmark (DE), Estonia (EE), Finland (FI), France (FR), Germany (DE), Greece (EL), Hungary (HU), Ireland (IE), Italy (IT), Latvia (LV), Lithuania (LT), Luxembourg (LU), Malta (MT), Netherlands (NL), Poland (PL), Portugal (PT), Romania (RO), Slovakia (SK), Slovenia (SI), Spain (ES), Sweden (SE), and United Kingdom (UK). Croatia was not considered in the research due to the high number of invalid entries present in the database provided by the European Commission (see 2017a).

3 Satisfaction with democracy used the micro-data provided by European Commission (2017a) in its standard Eurobarometer no. 79.3. Macro-level results related to satisfaction with democracy considered information of the report Public Opinion in the European Union-Standard Eurobarometer no. 79 (European Commission 2013, p. 72). Eurobarometer 79 consulted 27,105 people aged 15 years and over from 27 EU member states between the 10th and 26th of May 2013.

4 Such index is based on the aggregate-level results of the special issue no. 397 of the Eurobarometer series (European Commission 2014, p. 13, 46, and 56). This survey interviewed 26,786 people aged 15 years and over from 27 member states of the European Union (EU) between the 23rd February and the 10th March 2013. 
norms (compliance) versus social norms (expectations) - and these are not necessarily harmonious (Bauhr et al. 2010; De Sousa 2008; Heidenheimer 2002; Miller et al. 2001; Ledeneva 1998; Jos 1993; Gardiner 1992; Kjellberg 1992; Friedrich 1966)—and (2) two levels of anchorage-symbolic (morals) versus strategic (action) level (Becquart-Leclercq 1984). Moreover, social judgments are dynamic, varying in space and time (Galtung 2006; Lambsdorff 2006; Treisman 2007), across groups (Heidenheimer 2002), and depending on trade-offs between competing moral concerns (Dungan et al. 2014).

Special attention must be given to a few studies that tried to empirically link corruption and citizens' growing dissatisfaction with the way democracy works. In the Spanish case, Villoria et al. (2012, p. 92) found that "perceptions of corruption are associated with lower levels of satisfaction with democracy", while other scholars related the same effects when comparing countries worldwide (Anderson and Tverdova 2003; Dahlberg et al. 2015; Memoli and Pellegata 2013; Mishler and Rose 2001) or at the European level (see Pellegata and Memoli 2016; Stockemer and Sundström 2013; Wagner et al. 2009). In the opposite direction, Quaranta and Martini found that corruption had little bearing on public support for democracy in Southern Europe. What mattered, according to the authors, was "the overall economic performance and the simplified format of the political system in terms of a low number of parties, rather than how the system delivers policies, i.e. whether these are delivered through corrupt practices" (2017, p. 674). Similar to other studies in the field (see for e.g. Dahlberg et al. 2015; Wagner et al. 2009), these two authors opted for a public-office-centred (Nye 1967) operational definition of corruption (i.e. "the abuse of office for private gain"), which is more restricted in its applicability and explanatory potential.

In this article we propose a more encompassing public-interest-centred (Rogow and Lasswell 1977; Friedrich 1966) definition which is less focused on sporadic and individual criminal wrongdoing and more on the decline of ethical standards in public life (Johnston 1996) or the degeneration of the democratic culture in societies (Philp 1997a, pp. 37-38). In a nutshell, whereas corruption in the past was regarded as the exercise of illicit pressure through material and non-material inducements on the part of market actors upon public officials in order to distort or manipulate to their advantage, bureaucratic procedures and political decisions; today, corruption results primarily from a series of power strategies developed by certain economic agents with the intent of manipulating public policy and market regulation to their benefit, while passing the costs and moral hazards of these political and administrative decisions to the taxpayer. Everything takes place under the veil of legality and transparency. There is no criminal offence as such, yet decision-makers and their parties get rewarded for their services through revolving door and political financing practices.

All this is closely related to what Kaufmann and Vicente (2011, p. 199) refered as legal corruption, a construct that "is defined at the political level [and represents] a decision variable of the elite in power [and serves to] [...] the elite [to] build a legal framework to protect its own conduct"; or to what Lessig (2013, p. 553) described as institutional corruption,

[a] systemic and strategic influence which is legal, or even currently ethical, that undermines the institution's effectiveness by diverting it from its purpose or weakening its ability to achieve its purpose, including, to the extent relevant to its purpose, weakening either the public's trust in that institution or the institution's inherent trustworthiness. 
Corruption is no longer related to direct illicit implications, on the contrary, politics is transformed into a platform for a two-sided market where representatives and businessmen interact to perpetuate their own gains in an ambiance of normative support that formally gives the appearance of being democratic, but in practice is and is perceived by the general public as being intrinsically oligarchic (Maciel 2016, pp. 25-26). As Philp (2001, p. 358) conveniently reminds us, "[c]orruption is one way in which the exercise of political authority in a liberal democracy can go awry, subverting one or more of: the norms governing access, the legitimated exercise of authority, and/or the efficacy of accountability procedures".

In line with this approach, we now state our main hypothesis: the more citizens believe that policies are systematically being delivered through 'legal' corrupt practices (i.e. regulatory distortion, policy capture, favouritism), benefiting specific powerful groups in society at the expense of the majority, the more they will discredit the democratic functioning. In other words, evaluations of democratic performance appear to be more than an expression of sociographic conditions and/or of the incumbent's score in the economy because they are also influenced by (un)ethical behaviours. It is precisely this evidenced political inefficiency-caused specially by legal corruption-that needs further investigation.

In essence, corruption has been largely neglected when attempting to explain levels of satisfaction with democracy partly because very few authors (Castro 2008; Dincer and Johnston 2015; Kaufmann and Vicente 2011; Maciel 2016) have tried to define and measure corruption beyond the individual-oriented forms proscribed by law. We want to breakaway from this trend and propose to evaluate how perceptions on legal/institutional corruption affect citizens' satisfaction with democracy in EU-27 countries.

By claiming that European citizens are more concerned with the sociotropic (driven by broader social factors) than with the pocketbook (driven by individual evaluations) aspects of corruption, we expect to contest the mainstream literature on political support, which has traditionally focused on corruption as a criminal offence, measured in terms of personal experience with bribery (i.e. victimisation), and to emphasize that-albeit considering the strong explanatory power of individual-level determinants-such as perceptions on macroeconomic management and political attitudes - a broader understanding of social representations of corruption is necessary to decode regime dissatisfaction. The corruption that is troubling citizens' evaluation of democratic performance is not bribery per se, but legal/institutional corruption.

While some concurrent approaches-focusing on individual-level sociographics/personal characteristics ${ }^{5}$ and/or macroeconomic conditions (see Friedrichsen and Zahn 2010; Van Erkel and Van Der Meer 2016)_usually offer reasonable explanations for regime dissatisfaction, they underestimate political aspects ${ }^{6}$ and ignore the prevalence of

\footnotetext{
5 This approach is adopted by the vast majority of studies in the area in a complementary perspective. Studies about the evaluations of $D w D$ and corruption in Europe use individual social characteristics recurrently (Magalhães 2014, 2016; Pellegata and Memoli 2016; Quaranta and Martini 2017).

${ }^{6}$ Political attitudes (such as political participation, representation, quality of government, and corruption) sometimes appear as explanatory variables of $D w D$, influenced by macroeconomic determinants or microlevel sociographics (see for e.g. Dahlberg et al. 2015; Quaranta and Martini 2017; Stockemer and Sundström 2013). Foster and Frieden (2017, p. 21), for example, show that political institutions are secondary to economic factors in explaining trust in the democratic functioning of European countries. However, they only focus on the short-term change in levels of trust. Political factors (including 'beyond the law' aspects of corruption) matter to explain long-term rather than short-term regime performance. The widespread dissatisfaction with democracy is the result of a lengthy and corrosive process, in which current economic results usually blur the boundaries between what constitutes amoral and corrupt behaviour. Poor
} 
institutionalised ('beyond the law') forms of corruption in advanced democracies. We argue that it is precisely this legal corruption that makes citizens connect their perceptions of both economic downgrading (in macroeconomic terms) and disappointment with politics with their evaluations on declining democratic performance across Europe.

\section{Methods}

In order to test our hypothesis adequately and persuasively, it is necessary to provide an operational definition of legal corruption. Tacking stock of traditional public-interestcentred definitions, legal corruption can be conceptualized as "a disintegration of the belief system upon which a particular political system rests" (Friedrich 2002, p. 17). This systemoriented conceptualisation of corruption assumes different forms and it is expected to affect the democratic fiduciary relation between rulers and citizens (Newhouse 2014) by hindering the political system's legitimacy at three levels: at the (1) input level, by perverting the democratic idea that all have equal access to decision-making; at the (2) throughput level, by perverting the principles of transparency and accountability in politics; and at the (3) output level through a biased and dependent allocation of decisional goods and services to powerful groups in society. These dysfunctions correspond to three common occurrences or types of legal corruption-influence peddling, political financing informality, and policy capture.

In contexts where influence peddling-i.e. "efforts on the part of private interests to rent access and influence within well-institutionalized policy processes" (Johnston 2005, p. 3) -is recurrent, it becomes hard to guarantee non-biased governmental procedures/ decisions. Similarly, in situations where political financing informality prevails, policy decisions are either negotiated in secrecy to favour undisclosed private interests or blatantly favour large donors. In either case, it is clear that the methods and sources of political financing have a direct influence on the way public policies are designed and implemented hence it can determine the distribution of power in democracy. The lack of transparency and accountability (at the throughput level) combined with distorted access (at the input level) breeds a sense of procedural confidentiality and reinforces citizens' dissatisfaction with the functioning of democracies. If citizens are unable to see through the mechanisms of politics and understand how decisions are made, but have the feeling that these systematically serve a restricted group of powerful individuals and businesses, they tend to believe the democratic process has departed from its natural condition and evolved into something else that has little to do with the fostering of the public interest. Policy capture - or the situation in which "firms (or other private agents) [are] able to influence policy decisions" (Hellman and Schankerman 2000, p. 553) in order to benefit the interests of a circumscribed group of economic elites (Bagashka 2013, p. 167)—represents the quintessential output damage of the political-democratic process. If access is selective (at the input level) and the process is imbedded with secrecy and inconsistencies (at the throughput level), it is hard to conceive an unbiased and independent authoritative allocation of decisional goods (at the output level). It is the interrelation of these three processes - the declining of popular legitimacy at the input, throughput and output levels-

Footnote 6 continued

macroeconomic records may exert a short-term influence on the perceived dissatisfaction with the way democratic works, but only a sociotropic-oriented political corruption makes such dissatisfaction endemic, resilient and increasingly pronounced. 
that characterizes the resilient effect of sociotropic evaluations of corruption in democratic societies.

Using survey data from the European Commission for twenty-seven member states of the EU in 2013, we created a model to measure legal corruption, by merging its three dimensions-influence peddling, political financing informality, and policy capture-into a single aggregate indicator. This operationalization was made possible through a principal component analysis ${ }^{7}$ with consolidated data from the Special Eurobarometer no. 397 (see European Commission 2014). 'Illegal corruption', i.e. the abuse of office for private gain, was also measured using the same survey data. Dissatisfaction with democracy was operationalized by using survey data from the Standard Eurobarometer no. 79 (see European Commission 2013 for aggregated values, 2017a for microdata). Table 1 summarizes what has been discussed so far and presents in detail each proposed variable.

We also incorporated some controls ${ }^{8}$ into the discussion: a set of variables to capture the influence of the so-called individual sociographic characteristics-international experience/visited other EU country, marital status, years of formal education, school situation/if still studying at the present time, gender, age, employment status, urbanization/if living in a rural or urban area, household composition, income level, and Internet usage - other to describe personal economic and political attitudes (life satisfaction, political interest, situation of the national economy, and trust in political parties, national government, and national parliament); and another to evidence how macroeconomic performance interacts with the observed dissatisfaction with democracy in European countries (Gross domestic product (GDP) per capita, unemployment, shadow economy, and political stability). ${ }^{9}$

Econometric techniques were used to explore the specificities of both corruptions (legal and illegal) and the dissatisfaction with the democratic functioning in EU-27 countries. A multilevel approach was then adopted and a mixed-effects methodology for binary/binomial responses was applied in order to evidence the interaction between individual and country-level aspects when it comes to evaluate the perceived dissatisfaction with national democracies throughout the European continent. ${ }^{10}$

\section{Results and Discussion}

There seems to be widespread consensus in the mainstream literature on the quality of democracy that democracies have been dealing with critical levels of public support (see Morlino 2009; O'Donnell 2007). The same concern has been voiced by the European

\footnotetext{
7 A principal component analysis was used to merge all legal corruption dimensions into one. The KaiserMeyer-Olkin $(\mathrm{KMO})$ measure confirmed sample adequacy $(\mathrm{KMO}=0.645)$ for the proposed one-scale reduction, Bartlett's test of sphericity was significant at a $1 \%$ level, and Kaiser eigenvalue criterion was obeyed (explaining $68.16 \%$ of the variance in a single factor).

8 Sociographic individual-level variables and political determinants (at micro and macro levels) are usually used in studies about $D w D$ and corruption as controls (Dahlberg et al. 2015; Pellegata and Memoli 2016; Quaranta and Martini 2017; Stockemer and Sundström 2013; Wagner et al. 2009). Macroeconomic factors, albeit typically used in $D w D$ studies, serve to determine in which circumstances economic outcomes exert influence on political support at the aggregate level. Recent literature suggests that citizens tend to become particularly sensitive to occurrences of corruption affecting political actors, institutions, and processes in contexts of economic crisis (Choi and Woo 2010; Zechmeister and Zizumbo-Colunga 2013).

9 Table 3 in the Appendix details the full operationalization of all control variables used.

${ }^{10}$ Random-effects logit models were built using the Stata command 'xtlogit' and were grouped by countries.
} 
Table 1 Operationalizing main variables

Variables Operationalization

Legal corruption

Illegal corruption

Dissatisfaction with the way in which democracy operates $(D w D)$
A factorial combination (resulting in a single operational variable) of three questions of the Special Eurobarometer no. $397^{\mathrm{a}}$ : question QB4.3 “Talking more generally, if you wanted to get something from the public administration or public services, to what extent do you think it is acceptable to do a favour?" [measurement: percentage of 'total acceptable' answers per country/Values range from $0 \%$ (no acceptance) to $100 \%$ (total acceptance)/question related to influence peddling]; question QB15.12 "Please tell me whether you agree or disagree with... there is sufficient transparency and supervision of the financing of political parties in your country" [measurement: percentage of 'total agreement' answers per country/Values range from $0 \%$ (no agreement) to $100 \%$ (total agreement)/question related to political financing informality]; and question QB15.13 "Please tell me whether you agree or disagree with... In your country, the only way to succeed in business is to have political connections"

[measurement: percentage of 'total agreement' answers per country/Values range from $0 \%$ (no agreement) to $100 \%$ (total agreement)/question related to policy capture]. Final results were formatted in a standard normal distribution and the higher the values obtained, the higher the level of legal corruption

Citizens' responses to the question Q8 "Do you personally know anyone who takes or has taken bribes?" of the Special Eurobarometer no. $397^{\mathrm{b}}$. Measurement: aggregate percentage of 'Yes' answers per country. Values range from $0 \%$ (don't know a person) to $100 \%$ (everybody accepts bribes)

Citizens' responses to the question QA21a "On the whole, are you very satisfied, fairly satisfied, not very satisfied or not at all satisfied with the way democracy works in your country?" of the Standard Eurobarometer no. $79^{\mathrm{c}}$. A binary variable (1: not very satisfied or not at all satisfied; and 0 : very satisfied or fairly satisfied); that measures the 'not satisfied' answers per person in all EU-27 countries

Sources: ${ }^{\mathrm{a}}$ European Commission (2014, pp. 13, 46, and 56); ${ }^{\mathrm{b}}$ European Commission (2014, p. 70); and ${ }^{c}$ European Commission (2013, p. 72; 2017a, b)

Commission in regard to its member states: in general, EU countries have been experiencing alarming levels of democratic disillusion and contestation (Armingeon and Guthmann 2014; Leiter and Clark 2015). Most studies only explained such democratic disconnect in socioeconomic terms (see for e.g. Ehin 2007; Vigoda-Gadot et al. 2010). It is clear that a poor macroeconomic performance affects perceptions of the quality of experienced democracies (see Armingeon and Guthmann 2014; Clarke et al. 1993; Weßels 2015), especially in a period of crisis. However, citizens do not formulate and express their disappointment with democratic institutions exclusively in economic terms. Corruption, as previously discussed, should fill this gap and offer new interpretations and meanings for the process of detecting what influences the failure of democratic functioning.

Let us begin by depicting how Europeans express dissatisfaction with the way their respective national democracies work, by using survey data from the Eurobarometer no. 79 (European Commission 2013, p. 72). Figure 1 shows that Northern Europe and Benelux countries present residual levels of dissatisfaction, whereas both Eastern and Southern 


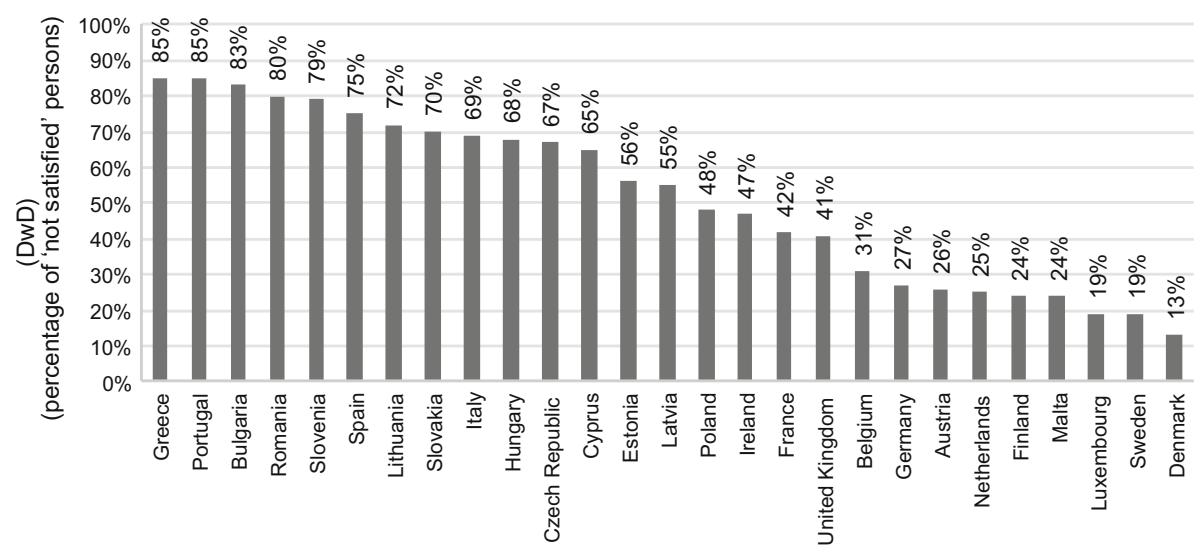

Fig. 1 Dissatisfaction with the way in which democracy operates in EU-27 member states (proportion of respondents who are 'not satisfied'). Source: European Commission (2013, p. 72)

European citizens appear to be mostly dissatisfied with their democracies. Disparities are clearly represented: countries like Greece (85\%), Portugal $(85 \%)$, Bulgaria $(83 \%)$, Romania (80\%), Slovenia (79\%), Spain (75\%), Lithuania (72\%), Slovakia (70\%), Italy (69\%), Hungary (68\%), and Czech Republic (67\%) display high levels of dissatisfaction with democratic performance. Differences in political culture have been suggested as a plausible explanation for the deviations observed (see for e.g. Brathwaite 2015; Dowley and Silver 2002; Karklins 2002; Mensah 2014; Zmerli and Newton 2008).

In a more detailed analysis, specific projections of the so-called political culture-such as social capital (see Ekici and Koydemir 2014; Newton 2006), institutions (see Criado and Herreros 2007; Kestilä-Kekkonen and Söderlund 2017), and/or procedural fairness (see Magalhães 2016) — seem to be correlated with attitudes supportive of democracy. Dissatisfied citizens have been associating economic crisis with cultural determinism and this combination has had an impact on specific support for the way democracy works because

the idea of democracy, its norms and its rules are so highly relevant to the people and constitutionally so strongly protected that for the time being any rollback of the normative dimension of democracy seems rather unlikely. This is, however, no reason for a false sense of security (Weßels 2015, p. 104).

This false sense of security is what makes citizens so frustrated. In our set of countries (EU-27), only three-Luxembourg (19\%), Sweden (19\%), and Denmark (13\%)—presented acceptable levels of dissatisfaction. The remaining 24 member states displayed more than $24 \%$ of dissatisfaction, which constitutes an alarming situation.

When looking at the interaction between legal/institutional corruption and levels of dissatisfaction with democracy (Fig. 2), we find that low levels of (perceived) political corruption do tend to be associated with positive judgements of the way democracies work, equivalent to what Zechmeister and Zizumbo-Colunga (2013) found regarding presidential approval in the Americas-higher levels of political corruption lead to lower levels of public support for the president. Figure 2 also shows that (with minor differences) the ordering of countries (and especially of regions in Europe) in terms of perceived legal corruption (as defined by its three-dimensional nature: influence peddling, political financing informality, and policy capture) is similar to that observed for the levels of dissatisfaction with the way democracy works (see Fig. 1). In other words, the higher the levels of perceived legal 


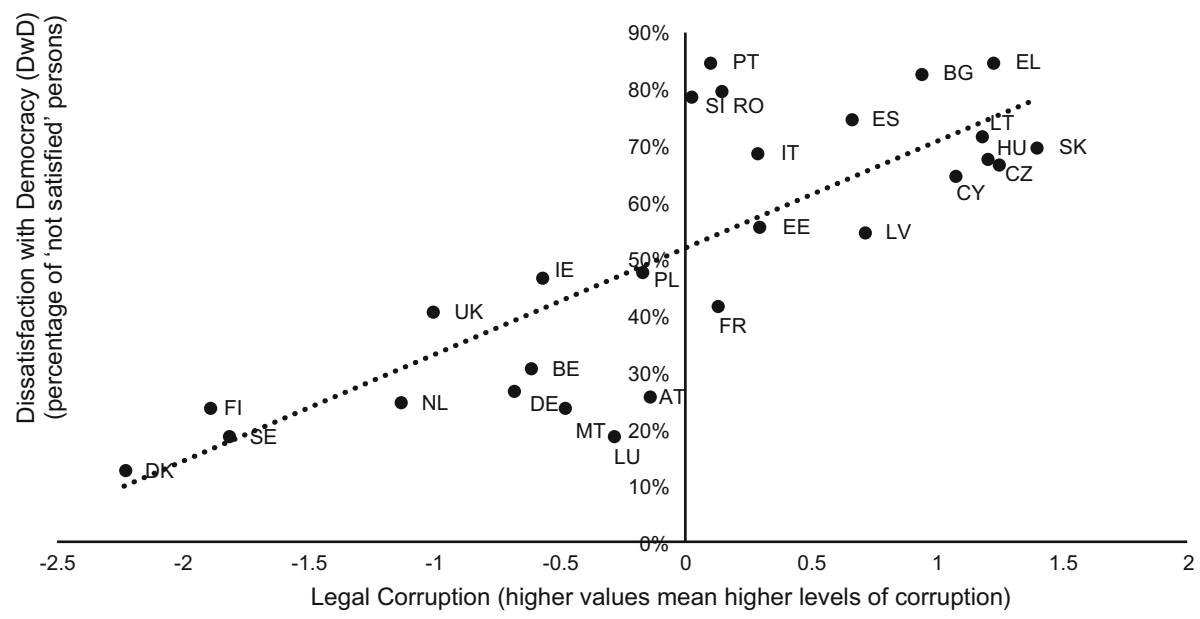

Fig. 2 'Dissatisfaction with the way in which democracy operates' versus 'legal corruption'. Source: European Commission (2013, p. 72; 2014, pp. 13, 46, 56 with adaptations)

corruption, the more deceived citizens are with democratic performance. The discrepancy among regions becomes even clearer in a Cartesian perspective. Both Southern and Eastern Europe appear at the top of the list of the 'most institutionally corrupt-dissatisfied', thus reinforcing the argument that political culture matters.

Stockemer and Sundström (2013, p. 152) found that "if people perceive the police or/ and the judges as corrupt, they will be less satisfied with their regime". Expanding on the conclusions made by these two authors, we believe that when citizens perceive corruption as a 'naturally sound condition of politics' (Philp 1997b, pp. 445-446), they are left with no credible institutional anchor or clear ethics referential for their conduct, hence they will tend to express chronic low expectations on democratic performance.

When it comes to illegal corruption, the data displays different results when compared to the patterns presented in Figs. 1 and 2. Most Eastern European countries also score high on corruption as a criminal offence, while most Southern European countries display very low scores. Portugal, Spain, and Italy improve dramatically their respective positions in the EU ranking when comparing to the already described 'Legal Corruption' counterpart (see Fig. 3). Thus, no apparent relation between illegal corruption and regime-functioning support is suggested. If there is no strong correlation between them, how could previous studies (see Anderson and Tverdova 2003; Dahlberg et al. 2015; Memoli and Pellegata 2013; Mishler and Rose 2001; Pellegata and Memoli 2016; Stockemer and Sundström 2013; Wagner et al. 2009) describe corruption as one of the possible determinants of citizens' dissatisfaction with the way democracy works? The answer is they could not. These studies have reduced the conceptualization of corruption to the abuse of office for private gain ${ }^{11}$ ignoring a series of practices in advanced democracies that clearly indicate a

\footnotetext{
11 All these studies were based on common sense concepts of corruption that describe it, with minor differences, as "the abuse of public office for private gain" (World Bank 1997, p. 8) or as "the abuse of entrusted power for private gain" (Transparency International 2016). In essence, they considered only illegal aspects of corruption (Anderson and Tverdova 2003, p. 92; Dahlberg et al. 2015, p. 32; Memoli and Pellegata 2013, p. 14; Mishler and Rose 2001, p. 317; Pellegata and Memoli 2016, p. 395; Stockemer and Sundström 2013, pp. 144-146; Wagner et al. 2009, p. 40) and neglected what matters the most: its capacity to create manipulation of public policies and market regulations.
} 


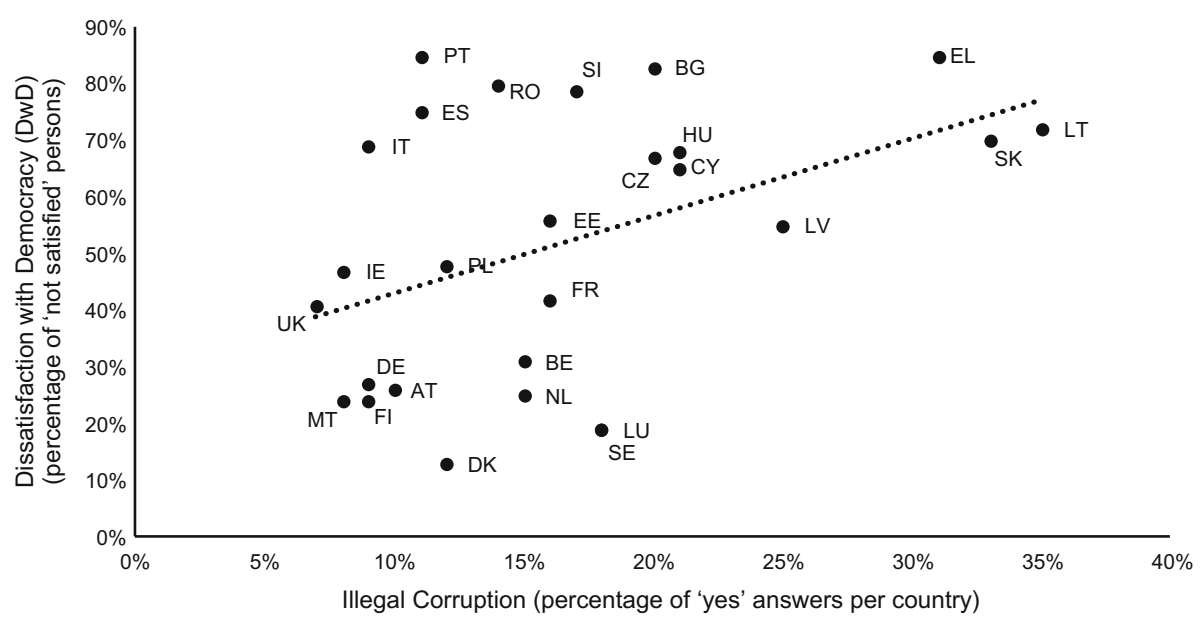

Fig. 3 'Dissatisfaction with the way in which democracy operates' versus 'illegal corruption' (European Commission 2013, p. 72; 2014, p. 70)

downgrading of ethical standards with a direct impact on levels of democratic legitimacy. It is precisely the nebulous aspects of corruption that are determining levels of satisfaction with democracy, hence they appear to be crucial to understand why European democracies are failing to deliver not only in terms of economic results, but also in terms of procedural fairness, political process, and ethical standards.

At a first glance, one might believe that dissatisfaction with democracy constitutes a pocketbook phenomenon, that is, a subjective evaluation based on one's own experience or social characterization. We argue that victimisation (in its different perspectives) is not determinant to explain increasing levels of $D w D$ and, because of that, corruption should not be regarded solely as an individual-level problématique. Considering responses from 23 waves of the Eurobarometer (conducted during the period 2004-2015), Foster and Frieden (2017) have identified that "economic factors explain much of the cross-national and over-time variation" in trust for national governments in Europe. They have also explored pocketbook dimensions of trust and found that levels of education and employment matter to determine confidence in European governments. Model 1 (see Table $2^{12}$ ) allows us to agree with what Foster and Frieden concluded, although with some caveats: dissatisfaction with democracy is determined in economic terms and not in individual terms. Personal characterization only matters when associated with economic conditions (only pocketbook economy-oriented variables were relevant to explain $D w D$ in Model 1).

Model 1 shows that, even without considering political elements, the greater contact citizens have with the social, political and economic reality of other EU countries ('International experience'), ${ }^{13}$ the possibility of achieving higher levels of education ('School

\footnotetext{
12 In multilevel models, when $\rho$ (rho)-i.e. the proportion of total variance contributed by the panel-level variance-is 0 , the panel-level variance component is unimportant and there is no need to run multilevel models. In this research, rho differs from 0 in all models, what constitutes an evidence for considering differences among countries. However, the values also indicate that the observations (albeit geographically dispersed) are homogenous throughout the entire set of European countries.

13 'International experience' presents promising results. It indicates that the more citizens visit other EU countries, the less they discredit their own national democracies. Future research is needed to disentangle such relation.
} 
Table 2 Determinants of the 'dissatisfaction with the way in which democracy operates'

\begin{tabular}{|c|c|c|c|c|c|c|}
\hline \multirow[t]{2}{*}{ Independent variables } & \multicolumn{2}{|l|}{ Model 1} & \multicolumn{2}{|l|}{ Model 2} & \multicolumn{2}{|l|}{ Model 3} \\
\hline & Coeff. & $\begin{array}{l}\text { Odds } \\
\text { ratio }\end{array}$ & Coeff. & $\begin{array}{l}\text { Odds } \\
\text { ratio }\end{array}$ & Coeff. & $\begin{array}{l}\text { Odds } \\
\text { ratio }\end{array}$ \\
\hline \multicolumn{7}{|c|}{ Individual level (social characterization) } \\
\hline International experience & $\begin{array}{l}0.271 * * * \\
(0.035)\end{array}$ & $\begin{array}{l}1.312 * * * \\
(0.046)\end{array}$ & & & $\begin{array}{l}0.169 * * * \\
(0.040)\end{array}$ & $\begin{array}{l}1.184 * * * \\
(0.047)\end{array}$ \\
\hline Marital status & $\begin{array}{l}0.037 \\
(0.038)\end{array}$ & $\begin{array}{l}1.038 \\
(0.039)\end{array}$ & & & $\begin{array}{l}0.058 \\
(0.044)\end{array}$ & $\begin{array}{l}1.060 \\
(0.046)\end{array}$ \\
\hline Years of education & $\begin{array}{l}-0.002 \\
(0.004)\end{array}$ & $\begin{array}{l}0.997 \\
(0.004)\end{array}$ & & & $\begin{array}{l}0.003 \\
(0.004)\end{array}$ & $\begin{array}{l}1.003 \\
(0.004)\end{array}$ \\
\hline School situation/regular student & $\begin{array}{l}0.538 * * * \\
(0.076)\end{array}$ & $\begin{array}{l}1.713^{* * *} \\
(0.130)\end{array}$ & & & $\begin{array}{l}0.066 \\
(0.089)\end{array}$ & $\begin{array}{l}1.068 \\
(0.095)\end{array}$ \\
\hline Gender & $\begin{array}{l}0.017 \\
(0.032)\end{array}$ & $\begin{array}{l}1.017 \\
(0.032)\end{array}$ & & & $\begin{array}{l}-0.020 \\
(0.037)\end{array}$ & $\begin{array}{l}0.980 \\
(0.036)\end{array}$ \\
\hline Age & $\begin{array}{l}-0.006^{* * * *} \\
(0.001)\end{array}$ & $\begin{array}{l}0.994 * * * \\
(0.001)\end{array}$ & & & $\begin{array}{l}-0.002 \\
(0.002)\end{array}$ & $\begin{array}{l}0.997 \\
(0.002)\end{array}$ \\
\hline Employment status & $\begin{array}{l}-0.132 * * * \\
(0.039)\end{array}$ & $\begin{array}{l}0.875^{* * *} \\
(0.034)\end{array}$ & & & $\begin{array}{l}-0.052 \\
(0.045)\end{array}$ & $\begin{array}{l}0.948 \\
(0.042)\end{array}$ \\
\hline Urbanization & $\begin{array}{l}-0.038^{*} \\
(0.021)\end{array}$ & $\begin{array}{l}0.961 * \\
(0.020)\end{array}$ & & & $\begin{array}{l}-0.020 \\
(0.024)\end{array}$ & $\begin{array}{l}0.979 \\
(0.023)\end{array}$ \\
\hline Household composition & $\begin{array}{l}-0.012 \\
(0.013)\end{array}$ & $\begin{array}{l}0.987 \\
(0.013)\end{array}$ & & & $\begin{array}{l}-0.001 \\
(0.015)\end{array}$ & $\begin{array}{l}0.998 \\
(0.015)\end{array}$ \\
\hline Income level & $\begin{array}{l}-0.437 * * * \\
(0.024)\end{array}$ & $\begin{array}{l}0.645^{* * * *} \\
(0.016)\end{array}$ & & & $\begin{array}{l}-0.238^{* * * *} \\
(0.028)\end{array}$ & $\begin{array}{l}0.787 \text { *** } \\
(0.022)\end{array}$ \\
\hline Internet usage & $\begin{array}{l}0.021 \\
(0.026)\end{array}$ & $\begin{array}{l}1.021 \\
(0.027)\end{array}$ & & & $\begin{array}{l}0.043 \\
(0.030)\end{array}$ & $\begin{array}{l}1.044 \\
(0.032)\end{array}$ \\
\hline \multicolumn{7}{|c|}{ Individual level (economic and political attitudes) } \\
\hline Life satisfaction & & & $\begin{array}{l}0.420 \text { *** } \\
(0.024)\end{array}$ & $\begin{array}{l}1.522 * * * \\
(0.036)\end{array}$ & $\begin{array}{l}0.385^{* * *} \\
(0.028)\end{array}$ & $\begin{array}{l}1.470 \text { *** } \\
(0.042)\end{array}$ \\
\hline Political interest & & & $\begin{array}{l}0.047^{* * * *} \\
(0.018)\end{array}$ & $\begin{array}{l}1.048^{* * * *} \\
(0.019)\end{array}$ & $\begin{array}{l}0.071 * * * \\
(0.021)\end{array}$ & $\begin{array}{l}1.073 * * * \\
(0.023)\end{array}$ \\
\hline Situation of the national economy & & & $\begin{array}{l}0.678^{* * * *} \\
(0.027)\end{array}$ & $\begin{array}{l}1.970 * * * \\
(0.054)\end{array}$ & $\begin{array}{l}0.651 * * * \\
(0.030)\end{array}$ & $\begin{array}{l}1.919 * * * \\
(0.058)\end{array}$ \\
\hline Trust in political parties & & & $\begin{array}{l}0.540 * * * \\
(0.056)\end{array}$ & $\begin{array}{l}1.716^{* * * *} \\
(0.096)\end{array}$ & $\begin{array}{l}0.567 * * * \\
(0.063)\end{array}$ & $\begin{array}{l}1.763^{* * * *} \\
(0.111)\end{array}$ \\
\hline Trust in national government & & & $\begin{array}{l}0.782 * * * \\
(0.052)\end{array}$ & $\begin{array}{l}2.187 * * * \\
(0.115)\end{array}$ & $\begin{array}{l}0.744 * * * \\
(0.059)\end{array}$ & $\begin{array}{l}2.106^{* * * *} \\
(0.123)\end{array}$ \\
\hline Trust in national parliament & & & $\begin{array}{l}0.841 * * * \\
(0.052)\end{array}$ & $\begin{array}{l}2.319 * * * \\
(0.120)\end{array}$ & $\begin{array}{l}0.844 * * * \\
(0.058)\end{array}$ & $\begin{array}{l}2.326^{* * * *} \\
(0.134)\end{array}$ \\
\hline \multicolumn{7}{|c|}{ Country-level (explanatory sociotropic perceptions) } \\
\hline Illegal corruption & $\begin{array}{l}-0.832 \\
(1.527)\end{array}$ & $\begin{array}{l}0.434 \\
(0.664)\end{array}$ & $\begin{array}{l}0.436 \\
(1.293)\end{array}$ & $\begin{array}{l}1.546 \\
(2.000)\end{array}$ & $\begin{array}{l}1.113 \\
(1.254)\end{array}$ & $\begin{array}{l}3.046 \\
(3.820)\end{array}$ \\
\hline Legal corruption & $\begin{array}{l}0.423^{* * * *} \\
(0.132)\end{array}$ & $\begin{array}{l}1.526^{* * * *} \\
(0.201)\end{array}$ & $\begin{array}{l}0.254^{* *} * \\
(0.110)\end{array}$ & $\begin{array}{l}1.289 * * \\
(0.142)\end{array}$ & $\begin{array}{l}0.232^{* *} \\
(0.108)\end{array}$ & $\begin{array}{l}1.262^{* *} \\
(0.136)\end{array}$ \\
\hline \multicolumn{7}{|c|}{ Country-level (macroeconomic controls) } \\
\hline log GDP per capita & $\begin{array}{l}-1.995^{*} \\
(1.113)\end{array}$ & $\begin{array}{l}0.135^{*} \\
(0.151)\end{array}$ & $\begin{array}{l}-1.443 \\
(0.942)\end{array}$ & $\begin{array}{l}0.236 \\
(0.223)\end{array}$ & $\begin{array}{l}-0.900 \\
(0.918)\end{array}$ & $\begin{array}{l}0.406 \\
(0.373)\end{array}$ \\
\hline $\log$ unemployment & $\begin{array}{l}1.517 * * \\
(0.677)\end{array}$ & $\begin{array}{l}4.560 * * \\
(3.088)\end{array}$ & $\begin{array}{l}-0.064 \\
(0.563)\end{array}$ & $\begin{array}{l}0.938 \\
(0.528)\end{array}$ & $\begin{array}{l}-0.135 \\
(0.557)\end{array}$ & $\begin{array}{l}0.872 \\
(0.486)\end{array}$ \\
\hline
\end{tabular}


Table 2 continued

\begin{tabular}{|c|c|c|c|c|c|c|}
\hline \multirow[t]{2}{*}{ Independent variables } & \multicolumn{2}{|l|}{ Model 1} & \multicolumn{2}{|c|}{ Model 2} & \multicolumn{2}{|c|}{ Model 3} \\
\hline & Coeff. & $\begin{array}{l}\text { Odds } \\
\text { ratio }\end{array}$ & Coeff. & $\begin{array}{l}\text { Odds } \\
\text { ratio }\end{array}$ & Coeff. & $\begin{array}{l}\text { Odds } \\
\text { ratio }\end{array}$ \\
\hline $\log$ shadow economy & $\begin{array}{l}0.218 \\
(0.873)\end{array}$ & $\begin{array}{l}1.243 \\
(1.086)\end{array}$ & $\begin{array}{l}1.002 \\
(0.745)\end{array}$ & $\begin{array}{l}2.724 \\
(2.028)\end{array}$ & $\begin{array}{l}1.105 \\
(0.718)\end{array}$ & $\begin{array}{l}3.021 \\
(2.169)\end{array}$ \\
\hline Political stability & $\begin{array}{l}-0.278 \\
(0.320)\end{array}$ & $\begin{array}{l}0.757 \\
(0.242)\end{array}$ & $\begin{array}{l}0.061 \\
(0.269)\end{array}$ & $\begin{array}{l}1.063 \\
(0.286)\end{array}$ & $\begin{array}{l}0.013 \\
(0.262)\end{array}$ & $\begin{array}{l}1.013 \\
(0.266)\end{array}$ \\
\hline \multicolumn{7}{|l|}{ Panel-level variance components } \\
\hline $\ln \sigma_{v}^{2}$ (natural $\log$ of the variance) & \multicolumn{2}{|c|}{$-1.723(0.286)$} & \multicolumn{2}{|c|}{$-2.067(0.285)$} & \multicolumn{2}{|c|}{$-2.166(0.297)$} \\
\hline$\sigma_{v}$ (standard deviation) & \multicolumn{2}{|c|}{$0.422(0.060)$} & \multicolumn{2}{|c|}{$0.356(0.051)$} & \multicolumn{2}{|c|}{$0.338(0.050)$} \\
\hline$\rho$ (rho) & \multicolumn{2}{|c|}{$0.051(0.014)$} & \multicolumn{2}{|c|}{$0.037(0.010)$} & \multicolumn{2}{|c|}{$0.033(0.010)$} \\
\hline \multicolumn{7}{|l|}{$N$} \\
\hline Respondents & \multicolumn{2}{|l|}{19,956} & \multicolumn{2}{|l|}{19,956} & \multicolumn{2}{|l|}{19,956} \\
\hline Countries & \multicolumn{2}{|l|}{27} & \multicolumn{2}{|l|}{27} & \multicolumn{2}{|l|}{27} \\
\hline
\end{tabular}

Statistically significant $*(10 \%$ level $) ; * *(5 \%$ level $) ; * *(1 \%$ level $) /$ standard errors in brackets

Situation/Regular Student'), the 'Employment Status', and 'Income Level' are especially relevant to explain dissatisfaction with democracy in Europe, thus confirming previous findings (Foster and Frieden 2017; see for e.g. Stockemer 2013; Van Erkel and Van Der Meer 2016). However, all these individual level variables are associated with important distributive issues. ${ }^{14}$ When it comes to corruption (Model 1), it is important to emphasize that this is the only institutional-oriented determinant of $D w D$ with statistical significance. Legal corruption is the link between the evidenced economic downgrading and the declining democratic performance across Europe. It symbolizes what citizens classify as abusive of the common interest and of the ideals of fairness and justice in democracy. It is legal corruption rather than illegal corruption that offers a sound explanation for declining levels of satisfaction with democracy in EU-27 in a context of crisis.

However, Foster and Frieden have also claimed that "short-term economic fluctuations as a result of the sovereign debt crisis are the main driver of the collapse in trust" (2017, p. 21). Such assertion ignores the fact that the perceived decline in regime performance is based on the evaluation of long-standing institutional dysfunctions leading to mounting public disappointment. Harteveld et al. (2013, p. 556) have found that when perceptions of corruption are used as a control variable, perceptions of the functioning of the national economy had no significant effect on levels of trust in the European Union. Models 2 and 3 restate this conclusion in a different manner: (1) macroeconomic controls lose their explanatory power and (2) illegal corruption remains statistically not significant when political determinants are added. In other words, analyses that neglect the political culture (like Model 1 does) are more likely to underline the importance of the macroeconomic

\footnotetext{
14 'Urbanization' (area of residence rural/urban) and 'age' present certain level of statistical significance (1 and $10 \%$, respectively) and display coefficients near $0(-0.038$ and -0.006 , respectively), what makes their contribution to the model extremely limited. Moreover, it is possible to argue that the relation ruraldissatisfaction raises a distributive problem because large cities concentrate public services and are central to the design of contemporary public policies. 'Age' could be seen as a complementary variable that describes intergenerational differences about $D w D$, young people have been facing difficulties in finding formal jobs, thus making them more susceptible of criticizing democratic performance and connect their evaluations with the 2008/2010 economic crises discourse.
} 
short-term national performance as a valid explanation of the citizens' dissatisfaction with democracy. It is the political context that determines, in the long run, citizens' deception with the democratic performance, not their intrinsic personal characteristics or even the deterioration of their countries' economic situation, in so far as the European context is concerned.

Illegal corruption does not prove to be statistically significant in our models (see Table 2 again). Considering social individual characteristics and macroeconomic controls (Model 1) or adding perceptions of political and economic aspects does not make this restricted conceptualization of corruption a reliable parameter to measure levels of dissatisfaction in the European Union. Model 2 validates such finding because it compares the adjustment of the macro-perceptions of corruption (both legal and illegal, produced by collective behaviour) with economic and political perceptions of the individuals. Again, no prevalence of illegal-based explanations has been found. On the contrary, it reinforces the explanatory value of the oft-neglected (legal) dimensions of corruption.

Higher levels of life satisfaction increase the likelihood of evaluating positively the performance of European democracies. Models 2 and 3 show that economic and institutional attitudes are relevant to dissatisfied democrats. In Model 1, social characterizationcombined with macroeconomic controls - appears as a prominent explanation of $D w D$ (as expected by the mainstream), however, in a more detailed analysis, the addition of perceptions of politics and economy to the models 2 and 3 makes clear that individual characteristics and countries' poor records in macroeconomic management overshadow the real determinants of dissatisfaction (only 'International experience remained statically significant): institutional inadequacy and reduced belief in the deliberative process of democracies and their inefficiency in combating situations of corruption. Moreover, 'Political Interest', 'Situation of the National Economy', and 'Trust in Political Parties, in National Government, and in National Parliament' appear as robust determinants of $D w D$ in models 2 and 3. Hobolt (2012) found similar results when evaluating $D w D$ in the European Union. For her, confidence in national parliament, economic evaluations, government approval, and quality of national institutions ${ }^{15}$ are necessary to decode regime support. Foster and Frieden (2017, p. 21) —although deconstructing the political explanation of the dissatisfaction with democracy-also accept that institutional quality ${ }^{16}$ is positively associated with the European trust/confidence in national governments. In different ways, these authors are saying the same: perceptions of political performance exert influence on regime support. Going a step further, models 2 and 3 not only present perceptions of politics and economy as relevant tools to decode $D w D$, but also declare that the absence of institutional quality observed in EU-27 countries is due to legal corruption.

While the literature has previously found that "high political interest more strongly enhances satisfaction with democracy than with life" (Stadelmann-Steffen and Vatter 2012, p. 544), ${ }^{17}$ models 2 and 3 show that the more dissatisfied citizens are, the more interest in politics they demonstrate. In fact, the logic here is the following: the more one

\footnotetext{
15 The quality of national institutions was measured considering five dimensions of the World Bank's Worldwide Governance Indicators (WGI): voice and accountability, government effectiveness, regulatory quality, the rule of law, and the control of corruption (see Kaufmann et al. 2009). In this case, corruption was indirectly used to perform the econometric exercises.

16 Institutional quality here refers to "an index developed by the International Country Risk Guide that provides a monthly rating of a country's bureaucratic quality, level of corruption, and, government responsiveness" (for more information, see Foster and Frieden 2017, p. 8 and note 6). Albeit indirectly, corruption was used to evaluate levels of trust in governments.

17 See also Lange and Onken (2013).
} 
engages in political actions that are fully inefficient and/or determined by amoral behaviours, the more one discredits the entire democratic process. It does not mean that Europeans which are not engaged think positively about regime functioning, it only means that they tend to be less stringent when evaluating $D w D$.

Due to such widespread discredit in institutions (as also observed in models 2 and 3), there is a growing tendency towards dissatisfaction when politics is considered a prominent topic to be discussed. In this line, Dalton's claim (1999, p. 69) that "there is at least indirect evidence that perceptions of the appropriate role for citizens now emphasizes a more participatory style and a greater willingness to challenge authority", constitutes a fruitful argument to be explored in future research.

By observing Table 2 we ratify what represents the quintessential argument of the paper: corruption has been neglected as a predictor of public support for democracy because of conceptual and methodological failings. The null hypothesis was rejected in all models, thus confirming that $D w D$ has a lot to do with perceptions of legal corruption rather than with experiences of bribery. Legal corruption displayed a strong adjustment in all models. Considering the EU-27 zone, our main hypothesis has been then validated.

\section{Conclusion}

Contrary to the mainstream literature, our findings suggest that legal corruption has been a driving factor of citizens' dissatisfaction with the way democracy works in EU-27. Further research should verify if other potential independent variables linked to the political culture-such as social capital and procedural fairness-enhance the results described here and in which circumstances they correlate with legal corruption. Furthermore, trying to explain $D w D$ by focusing primarily on individual sociographic variables and countries' short-term records in macroeconomic management also overshadows the important role played by legal/institutional corruption.

Although the democratization and consolidation trajectories of the different member states offer sufficient diversity in terms of institutional arrangements and political culture, we are aware that this is a European-centred research hence we would also suggest some caution in interpreting these results in other contexts. This being said, we encourage future works to replicate this model to other set of countries and regions of the world.

There are also some policy lessons that we can learn from this research exercise. It is necessary to reconfigure anti-corruption efforts to address the more nebulous, pervasive, and resilient institutional corruption. Legal corruption, and not just illegal corruption, undermines the trust of citizens in democratic institutions and processes. This, however, has largely been missing in the various integrity assessments produced by international and/or governmental organizations. Only recently have the issues of lobbying, revolving doors, and political financing started to being addressed, but always in a legalistic fashion, without taking into consideration informal mechanisms of exchange. These issues, which in some cases fall outside the regulated area, for e.g. informal lobbying or third party spending in electoral campaigns or even revolving door practices, can translate into mechanisms for buying political influence and thus feed the overall negative perception that citizens have about their political interlocutors and representatives.

Recalling on Max Weber's words of caution (1995 [1922]), the methods and sources of political financing can influence the way public policies are designed and implemented hence they can determine the distribution of power in democracy. When parties are 
perceived as mechanisms to access power by privileged groups in society, and its fundraising capacity depends on its market value, i.e. the capacity to deliver decisional goods and services to these groups once in office, thus becoming a normal feature of the policy process, citizens are likely to expect very little from their representatives and express low support for their important role in the daily running of democracy. Likewise, when parliamentarians sit in strategic committees, in particular those dealing with sensitive and profitable regulatory fields, such as healthcare, pensions and banking sector, while holding jobs as advisers in legislative affairs in multiple client law firms and consultancies, the risk of capture of law-making is real. This promiscuity between public and private interests portrays an image of 'business hub' that hinders the credibility of parliamentary politics. Conflicts of interest are a particularly relevant issue at a time when important and delicate policy decisions are taking place under the veil of austerity: from sensitive privatization processes to the renegotiations of concessions and public-private partnership (PPP) contracts, through the bailing out of private banks, there is a real fear that governments are not sufficiently independent from powerful economic groups.

This is a battle that cannot be won only by passing new anticorruption laws or strengthening law enforcement mechanisms. It requires a more comprehensive approach, which involves the fine-tuning of various institutions and processes affecting the daily running of politics, so as to allow democracy to perform better in ethical terms and recover its popular support.

Acknowledgements The authors are grateful to the reviewers and in particular to Pedro Magalhães, senior research fellow at the Institute of Social Sciences of the University of Lisbon (ICS-UL), for their detailed and helpful comments. Needless to say, the authors are solely responsible for the contents and any errors and omissions that may be detected in the article.

\section{Appendix}

See Table 3 .

Table 3 Operationalizing control variables

\begin{tabular}{|c|c|}
\hline Variables & Operationalization \\
\hline International experience ${ }^{a}$ & $\begin{array}{l}\text { Code qd6a_1/In the last } 12 \text { months have you visited another EU country?/0 } \\
\text { for 'yes' and } 1 \text { for 'no' }\end{array}$ \\
\hline Marital status $^{\mathrm{a}}$ & $\begin{array}{l}\text { Code } \mathrm{d} 7 \mathrm{r} 2 / \text { Could you give me the letter which corresponds best to your } \\
\text { own current situation?/1 for 'married' and } 0 \text { for 'other situations' }\end{array}$ \\
\hline Years of formal education ${ }^{a}$ & $\begin{array}{l}\text { Code d8/How old were you when you stopped full-time education?/age } \\
\text { when stopped studying }\end{array}$ \\
\hline $\begin{array}{l}\text { School situation/regular } \\
\text { student }^{\mathrm{a}}\end{array}$ & $\begin{array}{l}\text { Code d8r2/How old were you when you stopped full-time education?/1 for } \\
\text { 'non-students' and } 0 \text { for 'regular students' }\end{array}$ \\
\hline Gender $^{\mathrm{a}}$ & Code $\mathrm{d} 10 / 1$ for 'female' and 0 for 'male' \\
\hline Age $^{\mathrm{a}}$ & Code d11/age reported in years \\
\hline Employment status ${ }^{\mathrm{a}}$ & $\begin{array}{l}\text { Code d15a_r1/What is your current occupation?/1 for 'employment' and } 0 \\
\text { for 'unemployment' }\end{array}$ \\
\hline Urbanization $^{\mathrm{a}}$ & $\begin{array}{l}\text { Code } \mathrm{d} 25 / \text { Would you say you live in a rural area or village, small or middle } \\
\text { sized town, or large town?/2 for 'large town', } 1 \text { for 'middle sized town', } \\
\text { and } 0 \text { for 'rural area' }\end{array}$ \\
\hline
\end{tabular}


Table 3 continued

Variables $\quad$ Operationalization

Household composition $^{\mathrm{a}}$

Income level $^{\mathrm{a}}$

Internet usage $^{\mathrm{a}}$

Life satisfaction $^{\mathrm{a}}$

Political interest $\mathrm{t}^{\mathrm{a}}$

Situation of the national economy ${ }^{\mathrm{a}}$

Trust in political parties ${ }^{\mathrm{a}}$

Trust in national government ${ }^{\mathrm{a}}$

Trust in national parliament ${ }^{\mathrm{a}}$

Gross domestic product (GDP) per capita ${ }^{b}$

Unemployment rate

Shadow economy ${ }^{\mathrm{d}}$

Political stability ${ }^{\mathrm{e}}$
Code $\mathrm{d} 40 \mathrm{t} /$ Could you tell me how many people aged 15 years or more live in your household, yourself included?/number of people in household

Code d61r/On the following scale, step ' 1 ' corresponds to "the lowest level in the society"; step '10' corresponds to "the highest level in the society". Could you tell me on which step you would place yourself?/2 for the 'upper level', 1 for the 'middle level', and 0 for the 'lower level'

Code $\mathrm{d} 62 \mathrm{t} 1 /$ Could you tell me if you use the Internet at home, at your place of work, or somewhere else never, sometimes, or almost everyday?/3 for 'never', 2 for 'often/sometimes', 1 for 'everyday/almost everyday'

Code qa1/On the whole, are you very satisfied, fairly satisfied, not very satisfied or not at all satisfied with the life you lead?/4 for 'not at all satisfied', 3 for 'not very satisfied', 2 for 'fairly satisfied', and 1 for 'very satisfied'

Code polintr/When you get together with friends or relatives, would you say you discuss frequently, occasionally or never about national/European/ local political matters?/2 for 'frequently', 1 for 'occasionally', and 0 for 'never' for each dimension national, European, and local, the sum results in an index that categorizes citizens in 'strongly interested-4', 'moderately interested-3', 'slightly interested-2', or 'not at all interested in politics-1'

Code qa3a_1/How would you judge the current situation of the national economy?/4 for 'very bad', 3 for 'rather bad', 2 for 'rather good', and 1 for 'very good'

Code qa12_1/For each of the following institutions, please tell me if you tend to trust it or tend not to trust it: political parties./1 for 'tend not to trust' and 0 for 'tend to trust'

Code qa12_2/For each of the following institutions, please tell me if you tend to trust it or tend not to trust it: national government./1 for 'tend not to trust' and 0 for 'tend to trust'

Code qa12_3/For each of the following institutions, please tell me if you tend to trust it or tend not to trust it: national parliament./1 for 'tend not to trust' and 0 for 'tend to trust'

Information about the Gross Domestic Product (GDP) per capita for 2013 was obtained from the PORDATA Database

Unemployment rate considered percentages of persons aged 15 to 74 without a job, available for immediate employment, and/or actively seeking work during 2013

Shadow economy was measured as a monetary percentage of the 2013 GDP

Political stability used the 'Political Stability and Absence of Violence/ Terrorism' dimension of the Worldwide Governance Indicators (WGI) for the year 2013, which ranged from -2.5 (less stable) to +2.5 (more stable)

Sources: ${ }^{\text {a}}$ See European Commission (2017a) to access the entire dataset and European Commission (2017b) to consult the variable report data; ' $\mathrm{FFMS/Francisco} \mathrm{Manuel} \mathrm{dos} \mathrm{Santos} \mathrm{Foundation} \mathrm{(2016a);}{ }^{\mathrm{c}} \mathrm{FFMS} /$ Francisco Manuel dos Santos Foundation (2016b); ${ }^{\mathrm{d}}$ See Schneider (2015) for a detailed presentation; ${ }^{\mathrm{e}}$ See Kaufmann and Kraay (2016) 


\section{References}

Aarts, K., \& Thomassen, J. (2008). Satisfaction with democracy: Do institutions matter? Electoral Studies, 27(1), 5-18. https://doi.org/10.1016/j.electstud.2007.11.005.

Anderson, C. J., \& Tverdova, Y. V. (2003). Corruption, political allegiances, and attitudes toward government in contemporary democracies. American Journal of Political Science, 47(1), 91-109. https:// doi.org/10.1111/1540-5907.00007.

Armingeon, K., \& Guthmann, K. (2014). Democracy in crisis? The declining support for national democracy in European countries, 2007-2011. European Journal of Political Research, 53(3), 423-442. https://doi.org/10.1111/1475-6765.12046.

Bagashka, T. (2013). Unpacking corruption: The effect of veto players on state capture and bureaucratic corruption. Political Research Quarterly, 67(1), 165-180. https://doi.org/10.1177/1065912913492584.

Bailey, J., \& Paras, P. (2006). Perceptions and attitudes about corruption and democracy in Mexico. Mexican Studies/Estudios Mexicanos, 22(1), 57-82.

Bauhr, M., Nasiritousi, N., Oscarsson, H., \& Persson, A. (2010). Perceptions of corruption in Sweden. QoG working paper series (Vol. 8), Gothenburg, Sweden.

Becquart-Leclercq, J. (1984). Paradoxes de la corruption politique. Pouvoirs, revue française d'études constitutionnelles et politiques, 31, 19-36.

Brathwaite, R. T. (2015). Social distortion: Democracy and social aspects of religion-State separation. Journal of Church and State, 57(2), 310-332. https://doi.org/10.1093/jcs/cst095.

Canache, D., \& Allison, M. E. (2005). Perceptions of political corruption in Latin American democracies. Latin American Politics and Society, 47(3), 91-111. https://doi.org/10.1111/j.1548-2456.2005. tb00320.x.

Castro, C. (2008). Determinantes económicos da corrupção na União Europeia dos 15. Economia Global e Gestão, 13(3), 71-98.

Choi, E., \& Woo, J. (2010). Political corruption, economic performance, and electoral outcomes: A crossnational analysis. Contemporary Politics, 16(3), 249-262. https://doi.org/10.1080/13569775.2010. 501636.

Clarke, H. D., Dutt, N., \& Kornberg, A. (1993). The political economy of attitudes toward polity and society in Western European. The Journal of Politics, 55(4), 998-1021. https://doi.org/10.2307/2131945.

Criado, H., \& Herreros, F. (2007). Political support. Comparative Political Studies, 40(12), 1511-1532. https://doi.org/10.1177/0010414006292117.

Curini, L., Jou, W., \& Memoli, V. (2012). Satisfaction with democracy and the winner/loser debate: The role of policy preferences and past experience. British Journal of Political Science, 42(2), 241-261. https:// doi.org/10.1017/S0007123411000275.

Dahlberg, S., Linde, J., \& Holmberg, S. (2015). Democratic discontent in old and new democracies: Assessing the importance of democratic input and governmental output. Political Studies, 63(1_suppl), 18-37. https://doi.org/10.1111/1467-9248.12170.

Dalton, R. J. (1999). Political support in advanced industrial democracies. In P. Norris (Ed.), Critical citizens: Global support for democratic government (pp. 57-77). Oxford: Oxford University Press.

De Sousa, L. (2002). Corruption: Assessing ethical standards in political life through control policies. Doctoral thesis. Florence: European University Institute.

De Sousa, L. (2005). Reacções da opinião pública à corrupção e descontentamento com a democracia. In J. M. L. Viegas, A. C. Pinto, \& S. Faria (Eds.), Democracia: novos desafios e novos horizontes (pp. 277-302). Oeiras: Celta.

De Sousa, L. (2008). 'I Don't Bribe, I Just Pull Strings': Assessing the fluidity of social representations of corruption in Portuguese society. Perspectives on European Politics and Society, 9(1), 8-23. https:// doi.org/10.1080/15705850701825402.

De Sousa, L., Magalhães, P. C., \& Amaral, L. (2014). Sovereign debt and governance failures: Portuguese democracy and the financial crisis. American Behavioral Scientist, 58(12), 1517-1541. https://doi.org/ $10.1177 / 0002764214534666$.

Della Porta, D., \& Mény, Y. (Eds.). (1997). Democracy and corruption in Europe. London: Pinter.

Dincer, O., \& Johnston, M. (2015). Measuring illegal and legal corruption in American states: Some results from the Safra Center corruption in America Survey. Edmond J. Safra Research Lab Working Papers, 58, 1-41. http://ssrn.com/abstract=2579300.

Dowley, K. M., \& Silver, B. D. (2002). Social capital, ethnicity and support for democracy in the postcommunist states. Europe-Asia Studies, 54(4), 505-527. https://doi.org/10.1080/09668130220139145.

Dungan, J., Waytz, A., \& Young, L. (2014). Corruption in the context of moral trade-offs. Journal of Interdisciplinary Economics, 26(1-2), 97-118. https://doi.org/10.1177/0260107914540832. 
Ehin, P. (2007). Political support in the baltic states, 1993-2004. Journal of Baltic Studies, 38(1), 1-20. https://doi.org/10.1080/01629770701223486.

Ekici, T., \& Koydemir, S. (2014). Social capital, government and democracy satisfaction, and happiness in Turkey: A comparison of surveys in 1999 and 2008. Social Indicators Research, 118(3), 1031-1053. https://doi.org/10.1007/s11205-013-0464-y.

European Commission. (2013). Standard Eurobarometer no. 79. http://ec.europa.eu/public_opinion/ archives/eb/eb79/eb79_publ_en.pdf. Accessed 2 July 2016.

European Commission. (2014). Special Eurobarometer no. 397. http://ec.europa.eu/public_opinion/archives/ ebs/ebs_397_en.pdf. Accessed 2 July 2016.

European Commission. (2017a). Eurobarometer 79.3 (2013) (TNS opinion, Ed.). ZA5689 data file version 2.0.0. Brussels: GESIS Data Archive. https://doi.org/10.4232/1.12718.

European Commission. (2017b). Eurobarometer 79.3 (2013)_Variable report/codebook ZA5689. Brussels: GESIS Data Archive. https://doi.org/10.4232/1.12718.

Fackler, T., \& Lin, T. (1995). Political corruption and presidential elections, 1929-1992. The Journal of Politics, 57(4), 971-993. https://doi.org/10.2307/2960398.

FFMS/Francisco Manuel dos Santos Foundation. (2016a). GDP per capita (PPS). PORDATA database. http://www.pordata.pt/en/DB/Europe/Search+Environment/Table/5701020. Accessed 26 December 2016.

FFMS/Francisco Manuel dos Santos Foundation. (2016b). Unemployment rate, aged 15 to 74. PORDATA database. http://www.pordata.pt/en/DB/Europe/Search+Environment/Table/5701021. Accessed 26 December 2016.

Foster, C., \& Frieden, J. (2017). Crisis of trust: Socio-economic determinants of Europeans' confidence in government. European Union Politics. https://doi.org/10.1177/1465116517723499.

Friedrich, C. J. (1966). Political pathology. The Political Quarterly, 37(1), 70-85. https://doi.org/10.1111/j. 1467-923X.1966.tb00184.x.

Friedrich, C. J. (2002). Corruption concepts in historical perspective. In A. J. Heidenheimer \& M. Johnston (Eds.), Political corruption: Concepts and contexts (pp. 15-23). New Brunswick, NJ: Transaction Books.

Friedrichsen, J., \& Zahn, P. (2010). The macroeconomy and individuals' support for democracy. In 19th workshop on political economy, CWPE 1104.

Galtung, F. (2006). Measuring the immeasurable: Boundaries and functions of (macro) corruption indices. In C. Sampford, A. Shacklock, C. Connors, \& F. Galtung (Eds.), Measuring corruption (pp. 101-130). Hampshire: Ashgate.

Gardiner, J. A. (1992). Defining corruption. Corruption and Reform, 7(2), 111-124.

Harteveld, E., Van der Meer, T., \& De Vries, C. E. (2013). In Europe we trust? Exploring three logics of trust in the European Union. European Union Politics, 14(4), 542-565. https://doi.org/10.1177/ 1465116513491018.

Heidenheimer, A. J. (2002). Perspectives on the perception of corruption. In A. J. Heidenheimer \& M. Johnston (Eds.), Political corruption: Concepts and contexts (pp. 141-154). New Brunswick, NJ: Transaction Publishers.

Hellman, J., \& Schankerman, M. (2000). Intervention, corruption and capture: The nexus between enterprises and the state. The Economics of Transition, 8(3), 545-576. https://doi.org/10.1111/1468-0351. 00055 .

Hobolt, S. B. (2012). Citizen satisfaction with democracy in the European Union. Journal of Common Market Studies, 50(S1), 88-105. https://doi.org/10.1111/j.1468-5965.2011.02229.x.

Holmberg, S., \& Rothstein, B. (Eds.). (2012). Good government: The relevance of political science. Cheltenham: Edward Elgar Publishing Limited.

Johnston, M. (1996). The search for definitions: The vitality of politics and the issue of corruption. International Social Science Journal, 48(3), 321-335. https://doi.org/10.1111/1468-2451.00035.

Johnston, M. (2005). Syndromes of corruption: Wealth, power, and democracy. Cambridge: Cambridge University Press.

Jos, P. H. (1993). Empirical corruption research: Beside the (moral) point? Journal of Public Administration Research and Theory, 3(3), 359-375.

Karklins, R. (2002). Typology of post-communist corruption. Problems of Post-Communism, 49(4), $22-32$.

Kaufmann, D., \& Kraay, A. (2016). WGI full dataset. The Worldwide Governance Indicators (WGI) project. www.govindicators.org. Accessed 12 February 2017.

Kaufmann, D., Kraay, A., \& Mastruzzi, M. (2009). Governance matters VIII: Aggregate and individual governance indicators. Policy research working paper 4978. Washington, DC: World Bank. http:// documents.worldbank.org/curated/en/598851468149673121/Governance-matters-VIII-aggregate-andindividual-governance-indicators-1996-2008. 
Kaufmann, D., \& Vicente, P. C. (2011). Legal corruption. Economics and Politics, 23(2), 195-219. https:// doi.org/10.1111/j.1468-0343.2010.00377.x.

Kestilä-Kekkonen, E., \& Söderlund, P. (2017). Is it all about the economy? Government fractionalization, economic performance and satisfaction with democracy across Europe, 2002-13. Government and Opposition, 52(1), 100-130. https://doi.org/10.1017/gov.2015.22.

Kjellberg, F. (1992). Corruption as an analytical problem: Some notes on research in public corruption. Indian Journal of Administrative Science, 3(1-2), 195-221.

Klašnja, M., \& Tucker, J. A. (2013). The economy, corruption, and the vote: Evidence from experiments in Sweden and Moldova. Electoral Studies, 32(3), 536-543. https://doi.org/10.1016/j.electstud.2013.05. 007.

Klašnja, M., Tucker, J. A., \& Deegan-Krause, K. (2014). Pocketbook vs. sociotropic corruption voting. British Journal of Political Science, 46(1), 67-94. https://doi.org/10.1017/S0007123414000088.

Lambsdorff, J. G. (2006). Causes and consequences of corruption. In S. Rose-Ackerman (Ed.), International handbook on the economics of corruption (pp. 3-51). Cheltenham: Edward Elgar Publishing Limited.

Lange, D., \& Onken, H. (2013). Political socialization, civic consciousness and political interest of young adults. In M. Print \& D. Lange (Eds.), Civic education and competences for engaging citizens in democracies. Civic and political education (Vol. 3, pp. 65-76). Rotterdam: SensePublishers. https:// doi.org/10.1007/978-94-6209-172-6_6.

Ledeneva, A. V. (1998). Russia's economy of favours: Blat, networking and informal exchange. Cambridge: Cambridge University Press.

Leiter, D., \& Clark, M. (2015). Valence and satisfaction with democracy: A cross-national analysis of nine Western European democracies. European Journal of Political Research, 54(3), 543-562. https://doi. org/10.1111/1475-6765.12088.

Lessig, L. (2013). Foreword: 'Institutional corruption' defined. Journal of Law, Medicine and Ethics, 41(3), $553-555$.

Lewis-Beck, M. S. (1988). Economics and elections: The major western democracies. Ann Arbor, MI: University of Michigan Press.

Light, D. W. (2013). Strengthening the theory of institutional corruptions: Broadening, clarifying, and measuring. Edmond J. Safra Research Lab Working Papers, 2, 1-24. https://doi.org/10.2139/ssrn. 2236391.

Linde, J. (2012). Why feed the hand that bites you? Perceptions of procedural fairness and system support in post-communist democracies. European Journal of Political Research, 51(3), 410-434. https://doi.org/ 10.1111/j.1475-6765.2011.02005.x.

Maciel, G. G. (2016). Legal corruption: A way to explain citizens' perceptions about the relevance of corruption. Master's thesis. Aveiro: University of Aveiro.

Magalhães, P. C. (2014). Government effectiveness and support for democracy. European Journal of Political Research, 53(1), 77-97. https://doi.org/10.1111/1475-6765.12024.

Magalhães, P. C. (2016). Economic evaluations, procedural fairness, and satisfaction with democracy. Political Research Quarterly, 69(3), 522-534. https://doi.org/10.1177/1065912916652238.

Meehl, P. E. (1977). The selfish voter paradox and the thrown-away vote argument. The American Political Science Review, 71(1), 11-30. https://doi.org/10.2307/1956951.

Memoli, V. (2016). Unconventional participation in time of crisis: How ideology shapes citizens' political actions. Partecipazione e Conflitto, 9(1), 127-151. https://doi.org/10.1285/i20356609v9i1p127.

Memoli, V., \& Pellegata, A. (2013). Electoral systems, corruption and satisfaction with democracy. In XXVII annual conference of the Italian political science (pp. 1-40), Florence, Italy.

Mensah, Y. M. (2014). An analysis of the effect of culture and religion on perceived corruption in a global context. Journal of Business Ethics, 121(2), 255-282. https://doi.org/10.1007/s10551-013-1696-0.

Miller, W. L., Grødeland, A. B., \& Koshechkina, T. Y. (2001). A culture of corruption? Coping with government in post-communist Europe. Budapest: Central European University Press.

Mishler, W., \& Rose, R. (2001). Political support for incomplete democracies: Realist vs. idealist theories and measures. International Political Science Review, 22(4), 303-320. https://doi.org/10.1177/0192 512101022004002 .

Morlino, L. (2009). Legitimacy and the quality of democracy. International Social Science Journal, 60(196), 211-222.

Morris, S. D., \& Klesner, J. L. (2010). Corruption and trust: Theoretical considerations and evidence from Mexico. Comparative Political Studies, 43(10), 1258-1285. https://doi.org/10.1177/001041 4010369072.

Newhouse, M. E. (2014). Institutional corruption: A fiduciary theory. Cornell Journal of Law and Public Policy, 23(3), 553-594. https://doi.org/10.2139/ssrn.2335619. 
Newton, K. (2006). Political support: Social capital, civil society and political and economic performance. Political Studies, 54(4), 846-864. https://doi.org/10.1111/j.1467-9248.2006.00634.x.

Norpoth, H. (1996). The Economy. In L. LeDuc, R. G. Niemi, \& P. Norris (Eds.), Comparing democracies: Elections and voting in global perspective (pp. 299-318). Thousand Oaks, CA: Sage.

Nye, J. S. (1967). Corruption and political development: A cost- benefit analysis. The American Political Science Review, 61(2), 417-427.

O'Donnell, G. A. (2007). The perpetual crises of democracy. Journal of Democracy, 18(1), 5-11.

Pellegata, A., \& Memoli, V. (2016). Can corruption erode confidence in political institutions among European countries? Comparing the effects of different measures of perceived corruption. Social Indicators Research, 128(1), 391-412. https://doi.org/10.1007/s11205-015-1036-0.

Philp, M. (1997a). Defining political corruption. In P. Heywood (Ed.), Political corruption (pp. 20-46). Oxford: Blackwell.

Philp, M. (1997b). Defining political corruption. Political Studies, 45(3), 436-462.

Philp, M. (2001). Access, accountability and authority: Corruption and the democratic process. Crime, Law and Social Change, 36(4), 357-377. https://doi.org/10.1023/A:1012075027147.

Polavieja, J. (2013). Economic crisis, political legitimacy, and social cohesion. In D. Gallie (Ed.), Economic crisis, quality of work and social integration: The European experience (pp. 256-278). Oxford: Oxford University Press. http://www.oxfordscholarship.com/view/10.1093/acprof:oso/9780199664719.001. 0001/acprof-9780199664719-chapter-10.

Quaranta, M., \& Martini, S. (2017). Easy come, easy go? Economic performance and satisfaction with democracy in southern Europe in the last three decades. Social Indicators Research, 131(2), 659-680. https://doi.org/10.1007/s11205-016-1270-0.

Rock, M. T. (2009). Corruption and democracy. Journal of Development Studies, 45(1), 55-75. https://doi. org/10.1080/00220380802468579.

Rogow, A. A., \& Lasswell, H. D. (1977). Power, corruption, and rectitude. Westport, CT: Greenwood Press.

Rothstein, B. (2009). Preventing markets from self-destruction: The quality of government factor. QoG working paper series (Vol. 2). https://doi.org/10.2139/ssrn.1328819.

Rothstein, B. (2011). The quality of government: Corruption, social trust, and inequality in international perspective. Chicago, IL: University of Chicago Press.

Rothstein, B., \& Teorell, J. (2008). What is quality of government? A theory of impartial government institutions. Governance, 21(2), 165-190. https://doi.org/10.1111/j.1468-0491.2008.00391.x.

Sanches, E. R., \& Gorbunova, E. (2016). Portuguese citizens' support for democracy: 40 years after the carnation revolution. South European Society and Politics, 21(2), 211-226. https://doi.org/10.1080/ 13608746.2015.1130680.

Schneider, F. (2015). Size and development of the shadow economy of 31 European and 5 other OECD countries from 2003 to 2014: Different developments? Journal of Self-Governance and Management Economics, 3(4), 7-29. http://www.econ.jku.at/schneider.

Seligson, M. A. (2002). The impact of corruption on regime legitimacy: A comparative study of four Latin American countries. Journal of Politics, 64(2), 408-433. https://doi.org/10.1111/1468-2508.00132.

Stadelmann-Steffen, I., \& Vatter, A. (2012). Does satisfaction with democracy really increase happiness? Direct democracy and individual satisfaction in Switzerland. Political Behavior, 34(3), 535-559. https://doi.org/10.1007/s11109-011-9164-y.

Stockemer, D. (2013). Corruption and turnout in presidential elections: A macro-level quantitative analysis. Politics and Policy, 41(2), 189-212. https://doi.org/10.1111/polp.12012.

Stockemer, D., \& Sundström, A. (2013). Corruption and citizens' satisfaction with democracy in Europe: What is the empirical linkage? Zeitschrift für Vergleichende Politikwissenschaft, 7(S1), 137-157. https://doi.org/10.1007/s12286-013-0168-3.

Teixeira, C. P., Tsatsanis, E., \& Belchior, A. M. (2014). Support for democracy in times of crisis: Diffuse and specific regime support in Portugal and Greece. South European Society and Politics, 19(4), 501-518. https://doi.org/10.1080/13608746.2014.975770.

Thompson, D. F. (2013). Two concepts of corruption. Edmond J. Safra Research Lab Working Papers, 16, 1-24. https://doi.org/10.2139/ssrn.2304419.

Transparency International. (2016). What is corruption? http://www.transparency.org/what-is-corruption/. Accessed 16 March 2016.

Treisman, D. (2000). The causes of corruption: A cross-national study. Journal of Public Economics, 76(3), 399-457. https://doi.org/10.1016/S0047-2727(99)00092-4.

Treisman, D. (2007). What have we learned about the causes of corruption from ten years of cross-national empirical research? Annual Review of Political Science, 10(1), 211-244. https://doi.org/10.1146/ annurev.polisci.10.081205.095418. 
Van Erkel, P. F. A., \& Van Der Meer, T. W. G. (2016). Macroeconomic performance, political trust and the great recession: A multilevel analysis of the effects of within-country fluctuations in macroeconomic performance on political trust in 15 EU countries, 1999-2011. European Journal of Political Research, 55(1), 177-197. https://doi.org/10.1111/1475-6765.12115.

Vigoda-Gadot, E., Shoham, A., \& Vashdi, D. R. (2010). Bridging bureaucracy and democracy in Europe: A comparative study of perceived managerial excellence, satisfaction with public services, and trust in governance. European Union Politics, 11(2), 289-308. https://doi.org/10.1177/1465116510363657.

Villoria, M., van Ryzin, G. G., \& Lavena, C. F. (2012). Social and political consequences of administrative corruption: A study of public perceptions in Spain. Public Administration Review, 73(1), 85-94. https://doi.org/10.111/j.1540-6210.2012.02613.x.

Wagner, A. F., Schneider, F., \& Halla, M. (2009). The quality of institutions and satisfaction with democracy in Western Europe-A panel analysis. European Journal of Political Economy, 25(1), 30-41. https://doi.org/10.1016/j.ejpoleco.2008.08.001.

Waldron-Moore, P. (1999). Eastern Europe at the crossroads of democratic transition: Evaluating support for democratic institutions, satisfaction with democratic government, and consolidation of democratic regimes. Comparative Political Studies, 32(1), 32-62. https://doi.org/10.1177/0010414099032001002.

Warren, M. E. (2004). What does corruption mean in a democracy? American Journal of Political Science, 48(2), 328-343. https://doi.org/10.1111/j.0092-5853.2004.00073.x.

Weber, M. (1995 [1922]). Wirtschaft und Gesellschaft. Grundriss der verstehenden Soziologie (posthumous publication). In M. B. da Cruz (Trans.), Teorias Sociológicas (Vol. 1, pp. 727-728). Lisbon: Edições Fundação Calouste Gulbenkian.

Weßels, B. (2015). Political culture, political satisfaction and the rollback of democracy. Global Policy, 6(1), 93-105. https://doi.org/10.1111/1758-5899.12232.

World Bank. (1997). Helping countries combat corruption. http://www1.worldbank.org/publicsector/ anticorrupt/corruptn/corrptn.pdf. Accessed 5 April 2015.

Zechmeister, E. J., \& Zizumbo-Colunga, D. (2013). The varying political toll of concerns about corruption in good versus bad economic times. Comparative Political Studies, 46(10), 1190-1218. https://doi.org/ $10.1177 / 0010414012472468$.

Zmerli, S., \& Newton, K. (2008). Social trust and attitudes toward democracy. Public Opinion Quarterly, 72(4), 706-724. https://doi.org/10.1093/poq/nfn054. 